\title{
Implementation of a computer system for life: "Manage your refrigerator Bth- GTR"
}

\section{Implementación de una solución informática para la vida: El proyecto "Gestiona tu refrigerador Bth-GTR"}

HERNÁNDEZ CRUZ, Luz Maríał*, CARRERA LIRA, Dyan Itandehui, ORTIZ CUEVAS, Nancy Georgina and PANTÍ GONZÁLEZ, Daniel Alberto

Universidad Autónoma de Campeche. Facultad de Ingeniería

Instituto Tecnológico Superior de Hopelchén. Unidad de Proyectos

ID $1^{\text {st }}$ Author: Luz María, Hernández-Cruz / ORC ID: 0000-0002-0469-5298, Researcher ID Thomson: H-3153-2018, CVU CONACYT ID: 662220

ID $1^{\text {st }}$ Co-author: Dyan Itandehui, Carrera-Lira / ORC ID: 0000-0003-4076-3785, CVU CONACYT ID: 1136759

ID $2^{\text {nd }}$ Co-author: Nancy Georgina, Ortiz-Cuevas / ORC ID: 0000-0003-4191-9630, CVU CONACYT ID: 964285

ID $3^{\text {rd }}$ Co-author: Daniel Alberto, Pantí-González / ORC ID: 0000-0001-7577-7146, Researcher ID Thomson: ABH4985-2020, CVU CONACYT ID: 649888

DOI: $10.35429 / J I D .2021 .13 .5 .1 .9$

Received July 23, 2021; Accepted October 30, 2021

\begin{abstract}
This article carries out applied research for the use and integration of technology in everyday life. The main objective of the study is to apply Bluetooth technology in a project called "Manage your Bth-GTR refrigerator" with the use of a sensor, an Arduino card and the development of a mobile application that provides the user with the ability to handle information related to the temperature and humidity of the refrigerator, and at the same time, store and manage the supply of the products. The knowledge society faces the importance of information in any area of life, particularly its usefulness in devices for everyday use, which is critical and indispensable in our day to day. The assumed methodology is divided into two main phases: the analysis of the IT solution and the integration of the Technologies provided for this purpose. Finally, the functionalities of the implemented mobile application are specified. The proposal evidences the opportunity to carry out future studies on the use, application, integration and implementation of new technologies that provide the human being with efficient and useful tools for daily activities.
\end{abstract}

Daily life, Mobile technology, Bluetooth

\section{Resumen}

El presente artículo efectúa una investigación aplicada para el uso e integración de la tecnología en la vida cotidiana. El objetivo principal del estudio es aplicar la tecnología Bluetooth en un proyecto denominado "Gestiona tu refrigerador Bth-GTR" con el uso de un sensor, una tarjeta Arduino y el desarrollo de una aplicación móvil que proporcione la capacidad al usuario de manejar información relativa a la temperatura y humedad del refrigerador, y al mismo tiempo, almacene y gestione el abastecimiento de los productos. La sociedad del conocimiento encara la importancia de la información en cualquier ámbito de la vida, particularmente su utilidad en dispositivos de uso cotidiano, que tiene un carácter crítico e indispensable en nuestro día a día. La metodología asumida se divide en dos fases principales: el análisis de la solución informática y la integración de las Tecnologías previstas para tal fin. Por último, se concreta las funcionalidades de la aplicación móvil implementada. La propuesta evidencia la oportunidad de realizar estudios futuros en el uso, aplicación, integración e implementación de nuevas tecnologías que aprovisione al ser humano herramientas eficientes y útiles para actividades de su quehacer diario.

Vida cotidiana, Tecnología móvil, Bluetooth

Citation: HERNÁNDEZ CRUZ, Luz María, CARRERA LIRA, Dyan Itandehui, ORTIZ CUEVAS, Nancy Georgina and PANTÍ GONZÁLEZ, Daniel Alberto. Implementation of a computer system for life: "Manage your refrigerator Bth-GTR". Journal Innovative Design. 2021, 5-13: 1-9

$\dagger$ Researcher contributing as first author. 


\section{Introduction}

In today's world, communication between electronic devices is a basic technological need, in particular, for those that are available to everyone and are in daily use. Currently there are different technologies that allow the interconnection of devices. The project "Manage Your Refrigerator" (Bth-GTR) is a proposal, in which the user will have the ability to view the temperature of his refrigerator (temperature control), make a record of the products that it contains inside (product inventory) and a notification system. The computer solution proposes the development of a mobile application that stores and controls the temperature of the refrigerator, manages the inventory of consumable products and the notification system for inappropriate values of temperature or minimum quantity for supply; And, the use of Bluetooth technology for communication between the refrigerator and the mobile app.

Within the common Mexican household, $87.6 \%$ (INEGI, 2021) of the population has a refrigerator more than five years old. With this, it can be ensured that these devices do not have cutting-edge technology that allows managing information regarding the supply and control of the same. And, on the other hand, in this same sense, it is important to mention that refrigerators with intelligent technology are extremely high prices considering the Mexican minimum wage it would be impossible to acquire a refrigerator with these characteristics.

The comfort, flexibility, and proximity that people have with the use of the refrigerator in their homes, support the use of Bluetooth technology facilitating its connection with any mobile device.

are:

The sections that we find in this writing

The research project: briefly explains the study proposal;

- Methodology, description of the steps followed in the development of the case study; and, finally,

- Results cover the analysis, design, and implementation of the proposed IT solution.

\section{The research project: "Manage your Bth- GTR Refrigerator"}

The project 'Manage your refrigerator' (BthGTR) is an applied research proposal, through which technologies are integrated to develop a mobile application that serves the user to consult and restock their food inventory (consumables) in a more comfortable, easy, fast, and accessible way. The connection is made with Bluetooth technology, mainly due to its availability on mobile devices and undoubtedly facilitates the transfer of data over a short distance. In addition, it has a lower monetary value than Wi-Fi technology and does not need any specialized installation for its use. For this reason, it is the most appropriate resource to use in this proposal.

\section{Methodology}

In the research carried out, the emphasis of the study lies in the practical resolution of the application and integration of technologies that allow people to offer a computer solution to manage and supervise comfortably, easily, quickly, and in an economical way an object of daily use, the refrigerator. The project 'Manage your refrigerator' has as its main objective, to be able to have a device that provides the basic information (temperature, humidity, and inventory) to your mobile device, through a connection via Bluetooth.

The methodology assumed is divided into two steps described below:

1. Integration of technologies: describes the characteristics and functionality of the different technologies used in the computer solution of the Bth-GTR project.

Among which the following are distinguished:

Bluetooth module $\mathrm{Hc}-05$, which will allow connection via Bluetooth with the mobile application.

One Card R3 Atmega328 16u2 compatible Arduino with your USB cable, this will be the one that will receive the data and send it to the mobile application through the Bluetooth connection. 
- $\quad$ Humidity and temperature sensor dht11 Arduino / pic, through this, you can obtain the current temperature of the refrigerator and the humidity of it.

- $\quad$ Plate for the assembly of the circuit.

- Cables for connection between circuit components.

2. Bth-GTR IT Solution Analysis Stage: the requirements and design specification process for the Bth-GTR project are detailed.

Figure 1 represents the Methodology of the research study.

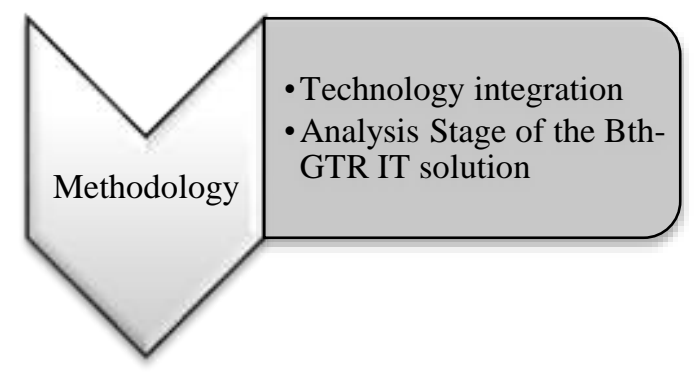

Figure 1 Methodology assumed in the Project "Manage your Bth-GTR refrigerator"

\section{Integration of Technologies in the Bth-GTR IT solution}

The technologies that are integrated into the Bth-GTR project's IT solution are listed below:

- Sensor humedad y temperatura DHT11. Humidity and temperature sensor DHT11. It is a digital sensor that measures temperature and humidity, it is a low-cost and easy-to-use sensor. It integrates a capacitive humidity sensor and a transmitter to measure the surrounding air and then display the data through a digital signal on the data pin, it should be noted that it has no analog output. It is commonly used with the accompaniment of an Arduino, with support for the 'Single bus' protocol. As for the hardware, it is only necessary to connect the VCC pin of power to $3-5 \mathrm{~V}$, the GND pin to ground $(0 \mathrm{~V})$, and the data pin to a digital pin of the Arduino. The only drawback of this type of sensor is that new data can only be obtained in 2 seconds. (SAC, Sensor de temperatura y humedad relativa DHT11, s.f.)

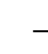

Bluetooth module HC-05. Bluetooth is a short-range, low-power wireless communications protocol in the 2.4 $\mathrm{GHz}$ ICM band that supports both data and audio traffic. Its link is so highly reliable that it makes the technology one of the most suitable for any type of application in digital communications, since it enables error detection mechanisms, offers a natural immunity to interference using a dispersed spectrum of frequency jump FHSS at 1600 jumps per second, and enables encryption processes to ensure reliable and secure communications.

The Bluetooth HC-05 module allows you to create the connection of projects with Arduino to a cell phone, smartphone PC wirelessly, with the ease of operation of a serial port, so the transmission is carried out completely transparently to the programmer. It connects directly to the serial pins of our preferred microcontroller (respecting the voltage levels, since the module is powered with $3.3 \mathrm{~V}$ )., this board also includes a $3.3 \mathrm{~V}$ regulator, which allows to power the module with a voltage between $3.6 \mathrm{~V}-6 \mathrm{~V}$.

- Bluetooth communication occurs between two types of devices: a master and a slave, however, the Bluetooth module HC-05 comes configured from the factory to work as a slave, that is, prepared to listen to connection requests, but we can configure it to work with Maestro using AT commands. Finally, it is important to mention that this module meets the specifications of the Bluetooth 2.0 standard that is perfectly compatible with Android phones or smartphones (SAC, Módulo Bluetooth HC05, s.f.) 
- $\quad$ Arduino Uno R3 card. The Arduino card is a free hardware board that incorporates a reprogrammable microprocessor and a series of female pins (which are internally attached to the I/O pins of the microcontroller) that allow different sensors and actuators to be connected in a very simple and comfortable way. The 'hardware board' refers specifically to a PCB ('Printed Circuit Board', which is a printed circuit board), these PBC's are surfaces made of a non-conductive material (usual resins of reinforced fiberglass, ceramic, or plastic) on which appear laminated tracks of conductive material (usually copper), are used to connect electrically, through the conductive paths, different electronic components welded to it, so it makes it a more compact and stable way to build an electronic circuit.

The way to connect the Arduino board to the computer is through a USB cable since most of these boards incorporate a connector of this type.(ARTERO, 2013).

The Arduino UNO R3 board is based on the ATmega328 microcontroller, with 14 digital input/output pins (of which 6 can be used as PWM outputs), 6 analog inputs, a $16 \mathrm{MHz}$ ceramic resonator, a USB connection, a power connector, an ICSP header, and a reset button. To be able to program the Arduino it is necessary to download the program that it includes and write the necessary code so that the board knows what to do.

Mobile application: The creation of the mobile application is developed in App inventor, which uses a type of programming quite colorful, fun, entertaining, and easy, in this case, this platform was chosen since it facilitates the interaction of Arduino and Bluetooth technology.

Having recognized the technologies, it is significant and transcendental to discern the core functionality they have in the Bth-GTR project's IT solution. Table 2 shows the technologies identified for the "Manage your Bth-GTR refrigerator" Project and their main function in it.

\begin{tabular}{|c|c|}
\hline Component. & Description \\
\hline $\begin{array}{lr}\text { Humidity } & \text { and } \\
\text { temperature } & \text { sensor } \\
\text { DHT11 } & \\
\end{array}$ & $\begin{array}{l}\text { The sensor measures the temperature } \\
\text { and humidity in the device where it is } \\
\text { installed. }\end{array}$ \\
\hline $\begin{array}{l}\text { Bluetooth module } \\
\text { HC-05. }\end{array}$ & $\begin{array}{l}\text { It allows connection with the use of } \\
\text { Bluetooth technology to other devices. }\end{array}$ \\
\hline $\begin{array}{lll}\text { Arduino } & \text { Uno } & \text { R3 } \\
\text { card. }\end{array}$ & $\begin{array}{l}\text { Free hardware board that incorporates } \\
\text { a reprogrammable microprocessor and } \\
\text { a series of pins-female that allow } \\
\text { connecting in a very simple and } \\
\text { comfortable way different sensors and } \\
\text { actuators. For this case the Humidity } \\
\text { and Temperature Sensor DHT11. }\end{array}$ \\
\hline Mobile App & $\begin{array}{l}\text { A type of application designed to run } \\
\text { on a mobile device with the ability to } \\
\text { use Bluetooth technology. }\end{array}$ \\
\hline
\end{tabular}

Table 2 Technological components and their main function in the Project 'Manage your Bth-GTR refrigerator'

Source: Own Source

\section{Analysis Stage of the Bth-GTR IT solution}

This section details the analysis that was carried out to manage and design the computer solution "Manage your Bth-GTR refrigerator". Framing the scope of the mobile application to be developed.

The initial question of the project is what? The requirements, according to the definitions in the IEEE glossary, the requirements are:

"A condition or need of a user to solve a problem or achieve a goal". (Std 610.12-1900, IEEE: 62).

"A condition or capability that must be present in a system or system components to satisfy a contract, standard, specification, or another formal document." (Std 610.12-1900, IEEE: 62).

A requirement is a description of a condition or capability that a system must meet, whether arising from an identified user need, or stipulated in a contract, standard, specification, or another document formally imposed at the beginning of the process. 
The requirements are divided into:

Functional requirements. They define the functions that the system will be able to perform, describe the transformations that the system performs on the inputs to produce outputs, it is important that the What? and not the How? these transformations must be made.

Non-functional requirements. They are the characteristics that in one way or another can limit the system, for example, performance (time and space), user interfaces, reliability (robustness of the system, availability of equipment), maintenance, security, and portability, among others. (CHAVES, 2005)

Table 3 shows the initial requirements of the Project "Manage your Bth-GTR refrigerator".

\begin{tabular}{|l|l|}
\hline \multicolumn{1}{|c|}{ ID } & \multicolumn{1}{c|}{ Description of the Requirement } \\
\hline R01 & Develop the circuit based on the diagram. \\
\hline R02 & $\begin{array}{l}\text { Design and implementation of programming on } \\
\text { the Arduino. }\end{array}$ \\
\hline R03 & $\begin{array}{l}\text { Develop the interface design for the mobile } \\
\text { application. }\end{array}$ \\
\hline R04 & $\begin{array}{l}\text { Coding of the application and interface based on } \\
\text { the design. }\end{array}$ \\
\hline
\end{tabular}

Table 3 Initial requirements of the Project "Manage your Bth-GTR refrigerator"

Source: Own Source

Use cases are a practice that is employed to capture a set of requirements and drive the incremental development of a system, this helps to understand how the system will be employed and then to evolve to an appropriate system that supports users. It makes clear what a system will do and, by intentional omission, what it will not do, just as, they enable effective vision, managing scope in the incremental development of software of any size.

Use cases can benefit both small agile development teams that produce heavy-lying applications and large projects that produce complex systems, such as corporate systems, product lines, and cloud systems.
Use cases have a much broader scope than just requirements capture, support the analysis, design, planning, estimation, monitoring, and testing of systems, provide a structure for the successful adoption of your curated management and development practices. In addition, the use cases are lightweight, scalable, versatile, and easy to use.(Ivar Jacobson, 2013).

Table 4 shows the Matrix of the relationship between the requirements and the use cases for the Project "Manage your refrigerator Bth-GTR"

\begin{tabular}{|c|c|c|c|c|c|c|}
\hline & & CU01 & CU02 & CU03 & CU04 & CU05 \\
\hline Req & irements/ Use Case & 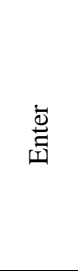 & 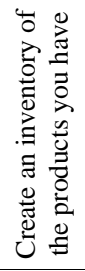 & $\stackrel{气}{\cong}$ & 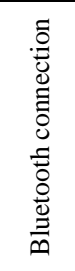 & 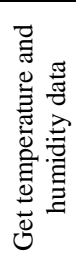 \\
\hline R01 & $\begin{array}{l}\text { Develop the circuit } \\
\text { based on the diagram. }\end{array}$ & & & & $\checkmark$ & $\checkmark$ \\
\hline R02 & $\begin{array}{lr}\text { Design } & \text { and } \\
\text { implementation } & \text { of } \\
\text { programming } & \text { in } \\
\text { Arduino. } & \\
\end{array}$ & & & & $\checkmark$ & $\checkmark$ \\
\hline R03 & $\begin{array}{l}\text { Develop the interface } \\
\text { design for the mobile } \\
\text { application. }\end{array}$ & $\checkmark$ & $\checkmark$ & $\checkmark$ & $\checkmark$ & $\checkmark$ \\
\hline R04 & $\begin{array}{l}\text { Coding of the } \\
\text { application } \\
\text { interface based on the } \\
\text { design. }\end{array}$ & $\checkmark$ & $\checkmark$ & $\checkmark$ & $\checkmark$ & $\checkmark$ \\
\hline R05 & $\begin{array}{l}\text { Establish a connection } \\
\text { between the sensor and } \\
\text { the application for } \\
\text { sending data. }\end{array}$ & & & & $\checkmark$ & $\checkmark$ \\
\hline
\end{tabular}

Table 4 Matrix of relationship Requirements/Use Cases of the Project 'Manage your Bth-GTR refrigerator' Source: Own Source

The importance of use cases lies in:

- $\quad$ Identify functions and how roles interact with them (the main purpose of use case diagrams).

- $\quad$ For a high-level view of the system.

- Especially useful when presented to managers or stakeholders. The roles that interact with the system and the functionality provided by the system can be highlighted without delving into the inner workings of the system.

- Identify internal and external factors. (ORDOÑEZ, CALVACHE, \& PINO, 2019) 
Given the importance of the use cases, the full description is made for each of them. Table 5 shows the description of the use case CU05 Obtain temperature and humidity data.

\section{CU05. Get temperature and humidity data.}

Version $0.3(21 / 04 / 2021)$

Dependencies

- R01 Develop the circuit based on the diagram.

- R02 Design and implementation of programming in Arduino.

- R03 Develop the interface design for the mobile application.

- R04 Coding of the application and interface based on the design.

- R05 Establish a connection between the sensor and the application for it sending data.

\section{Precondition}

The previous link between the application and the circuit had to be established.

Description

Humidity and temperature data will be obtained with the help of the sensor.

Normal sequence

\begin{tabular}{|c|l|}
\hline Step & \multicolumn{1}{|c|}{ Acction } \\
\hline 1 & The user enters the main page of the application. \\
\hline 2 & The user clicks the "continue" button \\
\hline 3 & The system directs you to the "Home" tab \\
\hline 4 & $\begin{array}{l}\text { The user clicks on the menu and chooses the } \\
\text { "Bluetooth" option. }\end{array}$ \\
\hline 5 & The system directs you to the "Bluetooth" tab \\
\hline 7 & $\begin{array}{l}\text { The user clicks the "connect" button. } \\
\text { connection displays the devices available for }\end{array}$ \\
\hline 8 & The user selects the Arduino device. \\
\hline 10 & $\begin{array}{l}\text { The system pairs with the selected device. } \\
\text { option. }\end{array}$ \\
\hline 11 & The system directs you to the "Home" tab \\
\hline 12 & $\begin{array}{l}\text { The system displays the temperature and humidity } \\
\text { data in the corresponding fields. }\end{array}$ \\
\hline Post-bestart
\end{tabular}

\section{Post-blessing}

Current refrigerator temperature and humidity data will be displayed in the app

Exceptions

\begin{tabular}{|c|l|l|}
\hline Step & \multicolumn{2}{|c|}{ Action } \\
\hline 7 & $\begin{array}{l}\text { The device for Bluetooth connection with the HC-05 } \\
\text { device cannot be found. }\end{array}$ \\
\cline { 2 - 3 } & E.1 & $\begin{array}{l}\text { The connection to the device is not } \\
\text { created. }\end{array}$ \\
\cline { 2 - 3 } & E.2 & $\begin{array}{l}\text { Temperature and humidity data } \\
\text { cannot be obtained from the } \\
\text { refrigerator. }\end{array}$ \\
\hline
\end{tabular}

\section{Feedback}

For the temperature and humidity of the refrigerator to be displayed in the application, the connection via Bluetooth must be established.

Table 5 Description of the USE case CU05 Obtain temperature and humidity data from the Project 'Manage your Bth-GTR refrigerator'

Source: Own Source

Use case diagrams are another indispensable and key tool at the analysis stage. They are composed of 4 basic elements:
1. Actor: The actor in a use case diagram is any entity that plays a role or role in a given system. It can be a person, an organization, or an external system and is usually drawn as the skeleton.

2. Use case: A use case represents a function or an action within the system. It is drawn as an oval and named with the function.

3. System: The system is used to define the scope of the use case and is drawn as a rectangle. This is an optional but useful element when viewing large systems. For example, you can create all the use cases and then use the system object to define the scope that your project covers. Or you can even use it to show the different areas covered in the different releases.

4. Package: The package is another optional element that is extremely useful in complex diagrams. Similar to class diagrams, packages are used to group use cases. They are drawn as the image below. (ORDOÑEZ, CALVACHE, \& PINO, 2019).

Figure 2 shows the general use case diagram for the Project "Manage Your BthGTR Refrigerator".

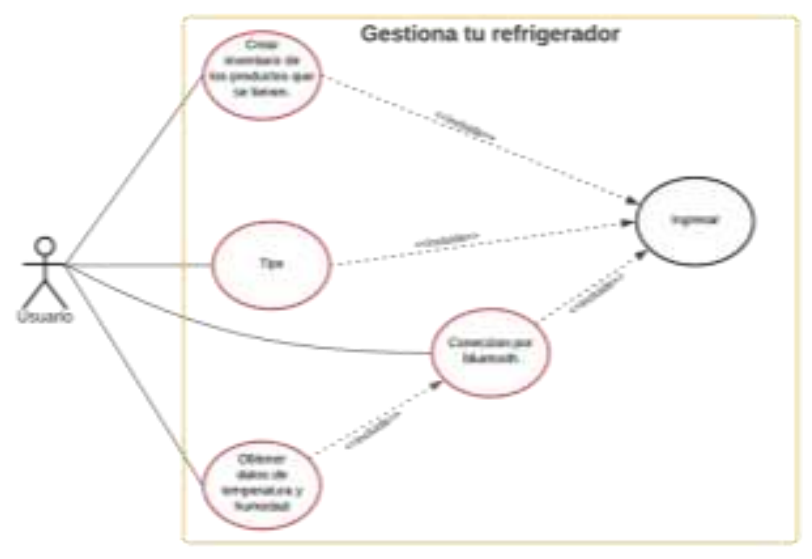

Figure 2 Principal Use Case Diagram for the project "Manage your refrigerator Bth-GTR" 


\section{Results}

Once the analysis phase is concluded, a functional prototype is made using the Fritzing software. Figure 3 shows the prototype and functional diagram of the physical connections of the Arduino Board and the Sensor for the project "Manage your refrigerator Bth-GTR".

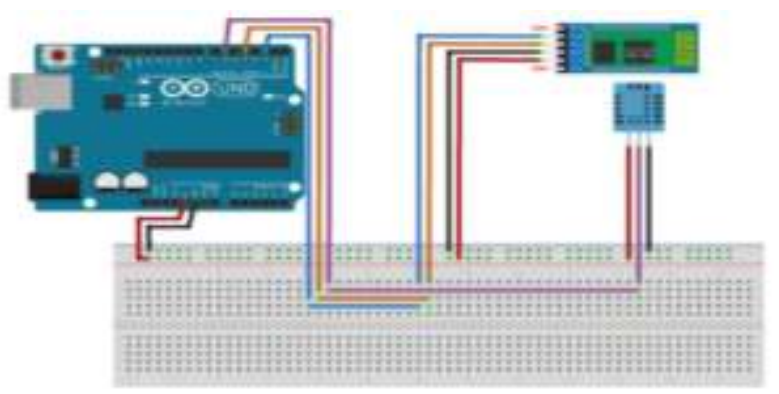

Figure 3 Arduino connection for the "Manage your BthGTR refrigerator" Project. Prototype and functional scheme

Next, Figure 4 shows the prototype of the connection in the project "Manage Your BthGTR Refrigerator".

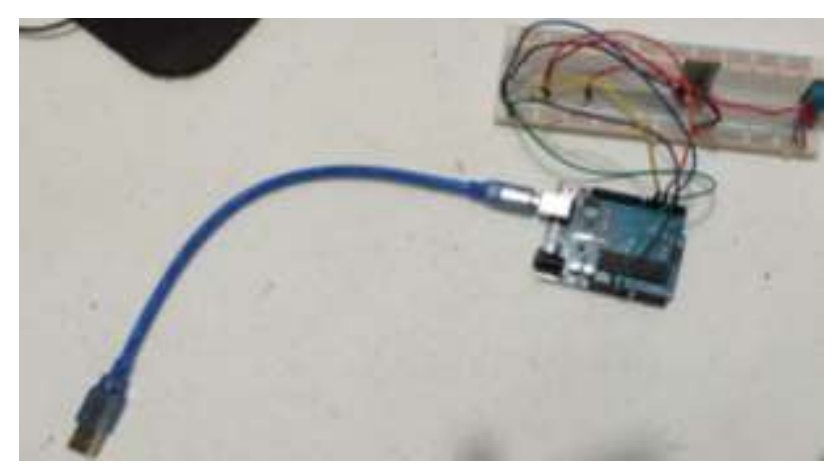

Figure 4 Project "Manage your refrigerator Bth-GTR"

Finally, Figure 5 shows the main interface of the App Bth-GTR and the TIPS section for users.

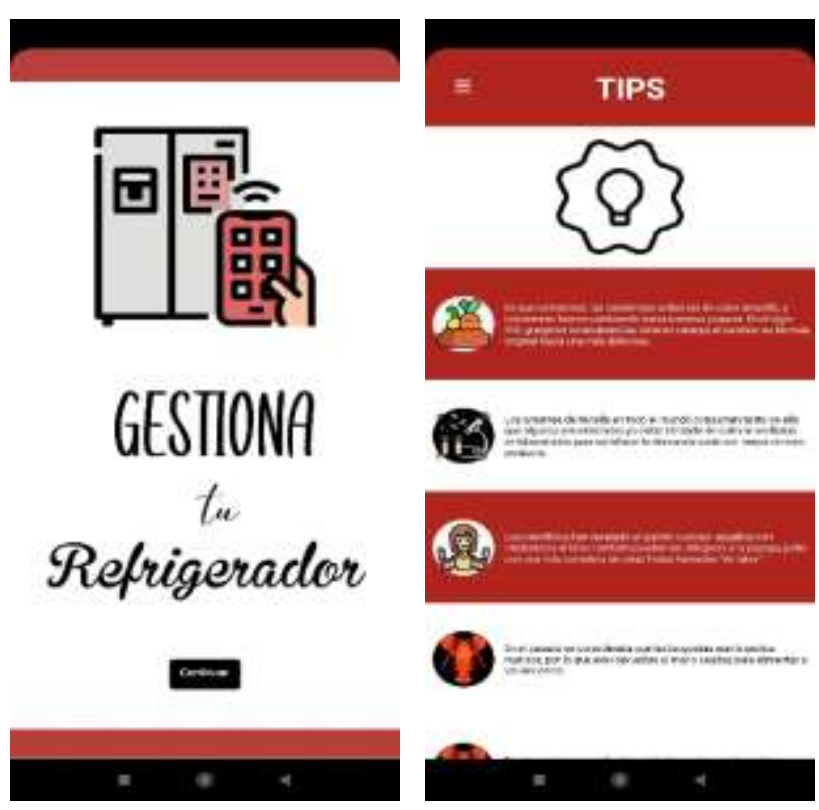

Figura 5 Home of the App Bth-GTR

The App Bth-GTR needs to activate the Bluetooth connection, otherwise the reading data from the refrigerator will not be loaded. It is important to mention that it is essential to be near the refrigerator. Figure 6 shows the Bluetooth connection interface prior to reading temperature and humidity.

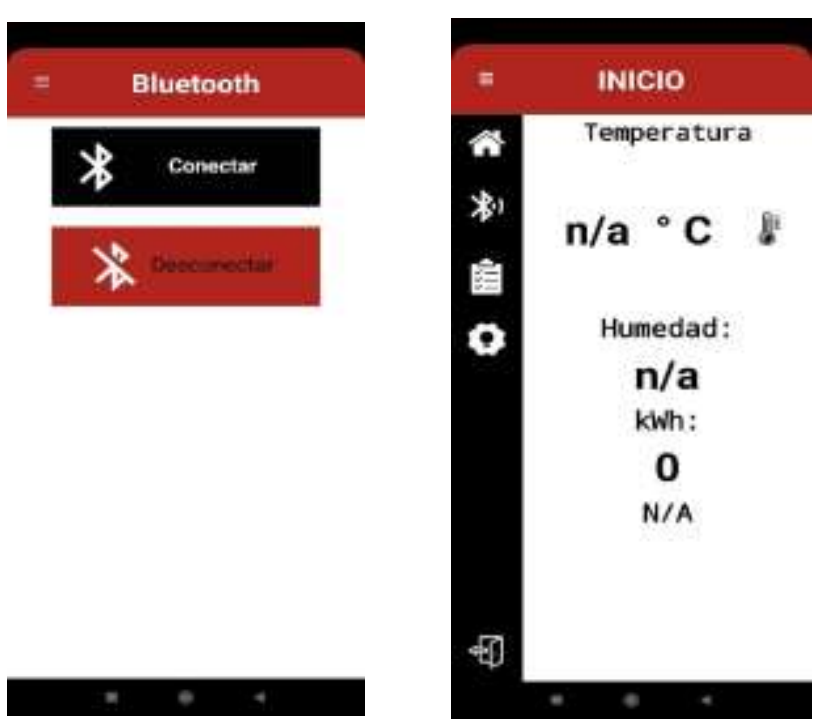

Figure 6 Interface for Bluetooth connection in the App Bth-GTR

Figure 7 shows an example of temperature and humidity reading within the App Bth-GTR. 


\section{$30^{\circ} \mathrm{C}$}

\section{Humedad:}

69

kWh:

\subsection{3}

Consumo de

energía

aceptable

Figure 7 Interface for Bluetooth connection in the App Bth-GTR.

Figure 8 shows the graphical user interface (GUI) for the supply, control and monitoring of consumable products in the refrigerator.

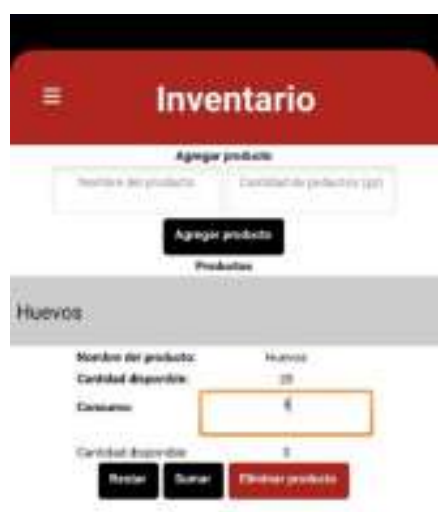

Figure 8 GUI of the App Bth-GTR

\section{Acknowledgements}

Broad gratitude is extended to the rector of the Unanimous University of Campeche for the disposition and support given for the publication of this article. Likewise, the recognition to the director of the Faculty of Engineering and to the coordinator of the Engineering in Computer Systems Educational Program for the empathy to boost the research studies in the Computer Sciences' area.

\section{Conclusions}

After doing the research, it is concluded that the mobile application "Manage your refrigerator Bth-GTR" has a stable connection via Bluetooth and allows the reading of temperature and humidity of the refrigerator. Also, the correct storage, control and monitoring of product inventory is carried out, including a notification system.

Customer expectations were successfully addressed. However, areas of opportunity are identified for the improvement of the IT solution. The possible advances that can be implemented include the use of other technologies such as Wi-Fi connection, so that it could have different connectivity conditions, in addition to the implementation of longdistance monitoring so that in this way there is more flexibility and user interaction with your refrigerator.

Last but not least, the implementation of the consumption module $(\mathrm{kWh})$ is expected to allow the refrigerator to be monitored every day. In addition, the user, in addition to having a better management of his refrigerator, would also have it in the consumption of electrical energy (economy).

\section{Referencies}

ARTERO, Ó. T. (2013). ARDUINO. Curso práctico de formación. RC Libros.

Borja Cameron, Ó. Á. (2018). Inovacion en electrodomesticos: Hacia un hogar eficiente, inteligente y conectado. Protiendas (70), 34 49.

CHAVES, M. A. (2005). La ingeniería de requerimientos y su importancia en el desarrollo de proyectos de software. (Vol. 6). InterSedes: Revista de las Sedes Regionales.

Herazo, L. (24 de 03 de 2021). ¿Qué es una aplicación móvil? Recuperado el 24 de 05 de 2021, de Anincubator Website: https://anincubator.com/que-es-una-aplicacionmovil/

Ivar Jacobson, I. S. (2013). Casos de uso 2.0. La guía para ser exitoso con los casos de uso. 
ORDOÑEZ, W. A., CALVACHE, C. J., \& PINO, F. J. (2019). Mapeo sistemático sobre la evaluación de la agilidad en organizaciones de desarrollo de software (Vol. 16). ITECKNE: Innovación e Investigación en Ingeniería,

RUIZ, R. L., VÁSQUEZ, J. A., \& LONDOÑO, G. A. (2004). Implementación del protocolo Bluetooth para la conexión inalámbrica de dispositivos electrónicos programables. (Vol. 10). Scientia et technica.

RUIZ, R. L., VÁSQUEZ, J. A., \& LONDOÑO, G. A. (2004). Implementación del protocolo Bluetooth para la conexión inalámbrica de dispositivos electrónicos programables. (Vol. 10). Scientia et technica.

SAC, N. M. (s.f.). Módulo Bluetooth HC05. Recuperado el 24 de 05 de 2021, de Naylamp Mechatronics - Perú: https://naylampmechatronics.com/inalambrico/ 43-modulo-bluetooth-hc05.html

SAC, N. M. (s.f.). Sensor de temperatura y humedad relativa DHT11. Recuperado el 24 de 05 de 2021, de Naylamp Mechatronics - Perú: https://naylampmechatronics.com/sensorestemperatura-y-humedad/57-sensor-detemperatura-y-humedad-relativa-dht11.html

SERNA, A., ROS, F., \& RICO, J. C. (2010). Guía práctica de sensores. Creaciones Copyright SL. 